Айгунов Жабраил Сайпутинович

аспирант

ФГАОУ ВО «Северо-Кавказский федеральный университет» г. Ставрополь, Ставропольский край

DOI $10.21661 / r-497940$

\title{
CRIMINAL RESPONSIBILITY FOR SUICIDE AND INCITEMENT TO SUICIDE
}

Аннотация: автор данной статьи уделяет особое внимание уголовной ответственности за самоубийство (cm. 110 УК РФ), особенностей его объективной и субъективной стороны и проблем квалификации при расследования данного преступления. Автором была предпринята попытка дать общую характеристику и выяснить правовое значение ответственности за доведение до самоубийства в законодательстве Российской Федерации.

Ключевье слова: самоубийство, доведение до самоубийства, 110 УК РФ, расследование, ответственность, законодательство Российской Федерации.

Abstract: in this article has been analyzed the criminal responsibility for suicide (Article 110 of the Russian Federation Criminal Code), the peculiarities of its objective and the subjective side, and qualification problems in the investigation of this crime. Objective: to give a general description, and find out the legal significance of the responsibility, for bringing to suicide in the legislation of the Russian Federation.

Keywords: suicide, bringing to suicide, Article 110 of the Russian Federation Criminal Code, investigation, responsibility, legislation of the Russian Federation.

Considering suicide in the diachronic space, it can be traced, that throughout this time, this concept has been closely intertwined with the life of any ethnic group, nation, and society.

For a long time, to this day, there were massive and isolated cases of suicide. But the attitude of society, as a whole, to commit suicide, it was always - negative.

There are several interpretations of the concept of «suicide». The basic concept is that which was given by E. Durkheim. 
E. Durkheim wrote: «suicide - is just a case of death, which directly, or indirectly is the result of a positive, or negative act, committed by the victim himself, if the latter was aware of the consequences of this act; the attempted suicide is a completely homogeneous action, but not carried through to the end» [1, p. 94].

Criminal offense, under article 110 of the Criminal Code, is dangerous to society. In the legislation of the Russian Federation, the consequences of bringing to suicide and an attempt on a person's life are provided for in article 110 of the Criminal Code of the Russian Federation, and other articles of the current Criminal Code of the Russian Federation.

In the Criminal Code of the Russian Federation, written methods of incitement to suicide: by threats, cruel treatment or systematic humiliation of human dignity [2, p. 37].

A prerequisite for criminal liability for incitement to suicide is the presence of the corresponding elements of a crime in the Criminal Code, because, otherwise, it will not be considered illegal, and will not be enshrined in the law on criminal liability.

Humiliation can be expressed in physical effects, such as torture, strikes in the presence of people, whose opinion of himself the victim appreciates.

Criminal liability under article 110 of the Criminal Code of the Russian Federation can occur, only if suicide, or an attempt on his life, has already taken place.

Types of suicides:

1. Objection - the motive of suicidal behavior - are revenge, causing damage to some other side. (Example: Chinese suicide as revenge against the abuser).

2. Appeal - the motive of suicidal behavior is to attract attention and thus make a difference. (Example: demonstrative self-immolations of dissidents).

3. Avoidance - this motive of behavior is characteristic for those cases when a person cannot escape in any other way from the threat hanging over him. (Example: A. Hitler's suicide).

4. Self-punishment - choosing such death, a person plays the role of a judge and the defendant in one person.

5. Refusing - the motive is to refuse of the existence [1, p. 145]. 
The offender can only be a natural, sane person who has reached 16 years of age. The subject of incitement to suicide can be any person. Thus, bringing to suicide is a crime under article 110 of the Criminal Code, represents a significant public danger.

It is characterized not only by the fact that it is affront to the natural human right the right to life, but also the exceptional cynicism, deceit, immorality, and directed against the humanistic principles in relationships between people.

Bringing a person to commit suicide or to attempt at suicide by threats, cruel treatment or systematic humiliation of human dignity of the victim - is punished by restriction of freedom for up to three years or imprisonment for up to five years.

Recently, Part Two of article 110 of the Criminal Code of the Russian Federation was introduced, which contains a number of qualifying signs. Later, the current Criminal Code of the Russian Federation was supplemented by articles 110. 1 -110. 2.

According to these additions, criminal liability is incurred for inclining to commit suicide or facilitating the commission of suicide (article 110.1 of the Criminal Code of the Russian Federation), as well as for organizing activities aimed at encouraging the commission of suicide (article 110. 2 of the Criminal Code of the Russian Federation).

\section{Список литературы}

1. Durkheim. E. Suicide (sociological etude) / E. Durkheim; [trans. from fr.]; under. ed. V. Lukova. - SPb.: Union, 1998. - 496 p.

2. Ilyin. N.N. Bringing Suicide to Suicide: Past and Present / N.N. Ilyin // Russian investigator. - 2016. - №23. - p. 38-41.

3. Ozhegov S.I., Shvedova N.Y. Etymological Dictionary of the Russian Language. 80,000 words and phraseological expressions. - M.: Temp, 2013 - 944 p.

4. Resolution of the Plenum of the Supreme Court of the Russian Federation No. 19 of October 16, 2009 «On Judicial Practice in Cases of Abuse of Official Powers and Excess of Official Powers» // Russian newspaper. - No. 207. - 10.30.2009. 